\title{
Allelopathic Activity and Chemical Analysis of the Essential Oil of Croton limae A. P. S. Gomes, M. F. Sales \& P. E. Berry (Euphorbiaceae)
}

\author{
Tiago R. Leite ${ }^{1}$, Maria A. P. Silva ${ }^{1}$, Marcos A. F. Santos ${ }^{1}$, Antônio C. B. Santos ${ }^{1} \&$ Natália Cavalcante da $\operatorname{Costa}^{1}$ \\ ${ }^{1}$ Post-graduate program in Molecular Bioprospection, Cariri Regional University, Crato, Brazil \\ Correspondence: Tiago R. Leite, Department of Chemistry, Post-graduate program in Molecular Bioprospection, \\ Cariri Regional University, Rua Cel. Antônio Luiz, 1161, 63100-000, Pimenta, Crato, Ceará, Brazil. Tel: \\ 55-88-998-390-149. E-mail: tiago.urca85@gmail.com
}

Received: July 2, 2015 Accepted: August 25, 2015 Online Published: October 15, 2015

doi:10.5539/jas.v7n11p90 URL: http://dx.doi.org/10.5539/jas.v7n11p90

\begin{abstract}
The allelopathic activity and chemical composition of the essential oil of Croton limae A. P. S. Gomes, M. F. Sales \& P. E. Berry (marmeleiro-prateado) have been evaluated in this study. The essential oil was extracted by hydro-distillation. A completely randomized design was used to test the influence of the essential oil from fresh leaves of $C$. limae in concentrations of $0.10 \%, 0.25 \%, 0.50 \%, 0.75 \%, 1 \%, 1.25 \%, 2.50 \%, 3.75 \%$, and $5 \%$ on the germination and growth of Lycopersicum esculentum Mill. (tomato) seeds by indirect contact, with a control using water and dimethyl sulfoxide (DMSO). Each treatment consisted of five replicates using twenty seeds in each one. The chemical analysis of the essential oil was carried out using gas chromatography coupled with mass spectrometry. The analysis showed the occurrence of 14 chemical compounds, the majority of which were cedrol (28.4\%), eucalyptol (17.4\%) and $\alpha$-pinene (13.8). The C. limae essential oil inhibited germination of the tomato seeds at concentrations of $2.50 \%$ and upwards and it affected the caulicles and radicles of tomatoes at all concentrations tested. The tests proved that $C$. limae presents phytotoxic activities.
\end{abstract}

Keywords: germination, growth, inhibition, allelochemicals, marmeleiro-prateado

\section{Introduction}

According to the National Health Surveillance Agency (ANVISA), Brazil has been the biggest consumer of pesticides worldwide since 2008, and this is due to intensive agricultural growth. In 2010, the Brazilian consumption of pesticides represented US $\$ 7.3$ billion, which corresponded to $14.25 \%$ of the world total of US $\$ 51.2$ billion (Molina, 2012). However, the large-scale use of pesticides has caused diverse environmental problems and human health hazards (Peres \& Moreira, 2007). With this in mind, it is important to develop alternatives weed control techniques through research of nontoxic pesticides which, unlike synthetic pesticides, do not cause damage to the environment. Thus the number of studies on allelopathic activity of flora elements has increased in recent decades.

Allelopathy encompasses various processes involving secondary metabolites production in plants, algae, bacteria and viruses, leading to direct influence on the growth and development of biological and agricultural systems (Gniazdowska \& Bogatek, 2005).

The plants of the Cerrado produce diverse secondary metabolites acting as defense mechanisms in response to the constant metabolic stress (water and nutritional shortages) that they are exposed to. The Cerrado biome has an important role in the maintenance and conservation of biodiversity, even though it occurs in relatively restricted areas, and is being threatened by the intense anthropogenic use of its natural resources. Therefore many efforts are currently being made to maintain and conserve these areas (Almeida, Proença, Sano, \& Ribeiro, 1998; Scariot, Silva, \& Felfili, 2005; Silva, Martim, Silva, Young, \& Ladeira, 2006).

The genus of Croton are rich in chemical compounds which have important biological activities (Matos, 2000). Some of these species have had their chemical and biological activities analyzed and verified, notably Croton argyrophylloides Müll. Arg., Croton cajucara Benth., Croton urucurana Baill., Croton sonderianus Müll. Arg., Croton zehntineri Pax. \& K. Hoffm. and Croton nepetifolius Baill. (Morais et al., 2006a; Oliveira-Junior, Silva, Araújo, Santos Júnior, \& Arnaud, 2008; Carneiro et al., 2011). 
Croton limae A. P. Gomes, F. Sales \& P. E. Berry was found in areas of Cerrado located in the Chapada do Araripe, in the south of the state of Ceará. This species was identified in 2009; it is still little known and no research on its allelopathic activity and chemical composition has been performed until now. Thus this study aims to analyze the allelopathic activity and chemical composition of the essential oil of $C$. limae.

\section{Materials and Methods}

Both vegetative phase material (leaves) for the essential oil extraction and reproductive phase material for the posterior botanical taxonomy of $C$. limae were collected between 8am and 10am in an area of Cerrado located in the Chapada do Araripe. The sample area is known as Barreiro Novo $\left(07^{\circ} 17^{\prime} 77^{\prime \prime} \mathrm{S}, 39^{\circ} 32^{\prime} 62^{\prime \prime} \mathrm{W}\right.$, altitude $\left.923 \mathrm{~m}\right)$. The collected material was kept in plastic bags and subsequently partly herborized and partly refrigerated. The taxonomic identification was carried out by Dr. Margareth Ferreira de Sales, a taxonomist from the Herbarium Sérgio Tavares (HST) located at the Federal Rural University of Pernambuco (UFPRE) in Recife - PE. The voucher specimens have been housed at the Herbarium Caririense Dárdano de Andrade-Lima (HCDAL), number 6285, located in the Cariri Regional University - URCA.

The essential oil of $C$. limae was extracted from the leaves by hydro-distillation. The leaves were weighed, crushed and kept in a volumetric flask coupled to a hydro-distillation unit containing distilled water in sufficient quantity to cover the leaves. The essential oil was removed two hours after the water began to boil and sodium sulfate was added to remove the remaining water. The oil was cooled for 24 hours. After this period the essential oil was removed and kept cooled for later use.

\subsection{Analysis of the Chemical Composition of the Essential Oil}

The chemical analysis of the essential oil was performed by gas chromatography coupled with mass spectrum (GC/MS) in a SHIMADZU instrument with mass selective detector QP5050A, operating on $70 \mathrm{eV}$ of ionization energy. A Capillary column Agilent DB-5HT $(30 \mathrm{~m} \times 0,25 \mathrm{~mm}$ of internal diameter $\times$ film thickness $0,1 \mu \mathrm{m})$ was used, with the following specifications: gun temperature of $270{ }^{\circ} \mathrm{C}$ gun and detector temperature of $290{ }^{\circ} \mathrm{C}$, using helium gas as carrier gas $(1.0 \mathrm{~mL} / \mathrm{min})$, linear speed of $47.3 \mathrm{~cm} / \mathrm{sec}$; total flux of $24 \mathrm{~mL} / \mathrm{min}$; carrier flux of $24 \mathrm{~mL} / \mathrm{min}$; pressure of $107.8 \mathrm{kPa}$; the oven temperature of the column was set to $60^{\circ} \mathrm{C}(2 \mathrm{~min})-180{ }^{\circ} \mathrm{C}(1$ min) at $4{ }^{\circ} \mathrm{C} / \mathrm{min}$ and $180-260{ }^{\circ} \mathrm{C}$ at $10{ }^{\circ} \mathrm{C} / \min$ (10 minutes).

The identification of the compounds was carried out by comparisons between the respective mass spectrum and patterns registered in the Wiley 229 database and between the retention index calculations and specialized literature values (Adams, 2001).

\subsection{Allelopathic Activity Assays}

The influence of the essential oil from leaves of the donor species $C$. limae collected in the Chapada do Araripe was tested on seed germination and seedling growth of the receptor species Lycopersicum esculentum Mill. by indirect contact. The assays were performed in the Laboratory of Applied Botany - LBA, of the Departament of Biological Sciences at the Cariri Regional University - URCA. L. esculentum was chosen as the receptor species due to presenting fast and uniform germination.

The allelopathic test was carried out by emulsifying the essential oil with dimethyl sulfoxide (DMSO) in the ratio 1 : 1 and then diluting in distilled water to give $15 \mathrm{~mL}$ solutions at concentrations of $0.10,0.25,0.50,0.75,1$; $1.25,2.50,3.75$ and $5 \%$; for the control group, a solution of DMSO and distilled water was used at a concentration of $1 \%$ (Table 1$)$. 
Table 1. Quantity of essential oil, dimethylsulfoxide and water to prepare solutions of the respective concentrations

\begin{tabular}{llll}
\hline Concentrations \% & Essential oil $\mu \mathrm{L}$ & Dimethyl sulfoxide (DMSO) $\mu \mathrm{L}$ & Water $\mu \mathrm{L}$ \\
\hline Control & - & 150 & 14850 \\
0.10 & 15 & 15 & 14970 \\
0.25 & 37.5 & 37.5 & 14925 \\
0.50 & 75 & 75 & 14850 \\
0.75 & 112.5 & 112.5 & 14775 \\
1 & 150 & 150 & 14700 \\
1.25 & 187.5 & 187.5 & 14625 \\
2.50 & 375 & 375 & 14250 \\
3.75 & 562.5 & 562.5 & 13825 \\
5 & 750 & 750 & 13500 \\
\hline
\end{tabular}

The treatments consisted of five repetitions each, using 20 seeds of the receptor species for each repetition, totaling 100 seeds per treatment. The seeds were sown in $9 \mathrm{~cm}$ diameter sterilized Petri dishes containing three filter papers moistened with $3 \mathrm{Ml}$ of distilled water. At the top of the Petri dishes, two filter papers were placed and $3 \mathrm{~mL}$ of solution at the appropriate concentration was added, following indirect contact methodology.

The assays were performed in a BOD type germination chamber set to a constant temperature of $25^{\circ} \mathrm{C}$ and photoperiod of $12 \mathrm{~h} / 12 \mathrm{~h}$ of light and dark during seven days. After this time, germination percentage and radicle and caulicle lengths were analyzed. The biometric analysis was conducted using a five seedling sample per repetition for each treatment.

A completely randomized design was used and the data was submitted to Analysis of Variance and Analysis of Regression, with the model best fitted to the data obtained being used (Figure 1).
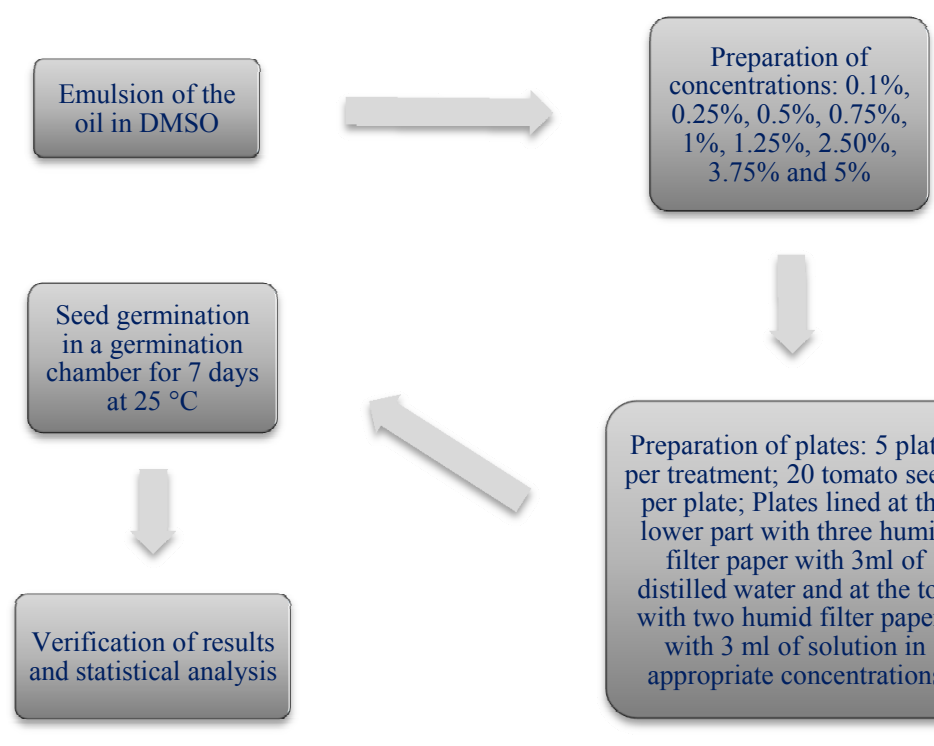

Figure 1. Diagram showing the methodology used in allelopathic test

\section{Results}

\subsection{Chemical Analysis of Essential Oil}

The yield of essential oil from the fresh leaves of $C$. limae, obtained from the leaf mass, was $0.36 \%$. In the chemical analysis of the oil, 14 compounds were identified and quantified, representing $84.7 \%$ of the total chemical composition. The main compounds were cedrol (28.4\%), eucalyptol (17.4\%) and $\alpha$-pinene (13.8\%), 
representing $59.6 \%$ of the total oil composition. The chemical compounds identified and their respective quantities, retention time and Kovats index are summarized in Table 2.

Table 2. Chemical compounds of the essential oil from fresh leaves of $C$. limae

\begin{tabular}{llll}
\hline Compounds & $\mathbf{R T}^{\mathbf{a}}(\mathbf{m i n})$ & $\mathbf{R I}^{\mathbf{b}}$ & $\mathbf{( \% )}$ \\
\hline$\alpha$-pinene & 5.2 & 939 & 13.8 \\
$\beta$-pinene & 6.2 & 980 & 3.0 \\
$\beta$-myrcene & 6.8 & 991 & 1.5 \\
$p$-cymene & 7.7 & 1026 & 4.2 \\
eucalyptol & 7.8 & 1033 & 17.4 \\
linalool & 10.1 & 1098 & 2.5 \\
cryptone & 12.8 & 1186 & 1.3 \\
p-cymen-8-ol & 12.8 & 1189 & 1.3 \\
$\beta$-caryophyllene & 20.1 & 1418 & 3.8 \\
$\alpha$-humulene & 21.1 & 1452 & 2.3 \\
alloaromadendrene & 21.2 & 1458 & 1.2 \\
Spathulenol & 22.9 & 1576 & 2.8 \\
cariofilene oxide & 23.7 & 1581 & 1.2 \\
cedrol & 24.9 & 1589 & 28.4 \\
Total identified & & & $\mathbf{8 4 . 7}$ \\
\hline
\end{tabular}

Note. ${ }^{\mathrm{a}}$ Retention time, ${ }^{\mathrm{b}}$ Kovats index (Adams, 2001).

\subsection{Effects of Allelopathic Activities of Essential Oil}

The essential oil of fresh leaves of $C$. limae exhibited meaningful inhibitory action on the germination of $L$. esculentum only at concentrations above $2.5 \%$ (Figure $2 \mathrm{a}$, Table 3 ). The caulicle length suffered meaningful reduction at all concentrations tested (Figure $2 \mathrm{~b}$, Table 3 ).

The result of the statistical analysis of the radicle biometric showed a meaningful reduction of radicular development in all treatments (Figure 2c, Table 3), verifying that increasing concentration caused a greater inhibition of the radical elongation, mainly at concentrations of $2.50 \%$ and $3.75 \%$. 

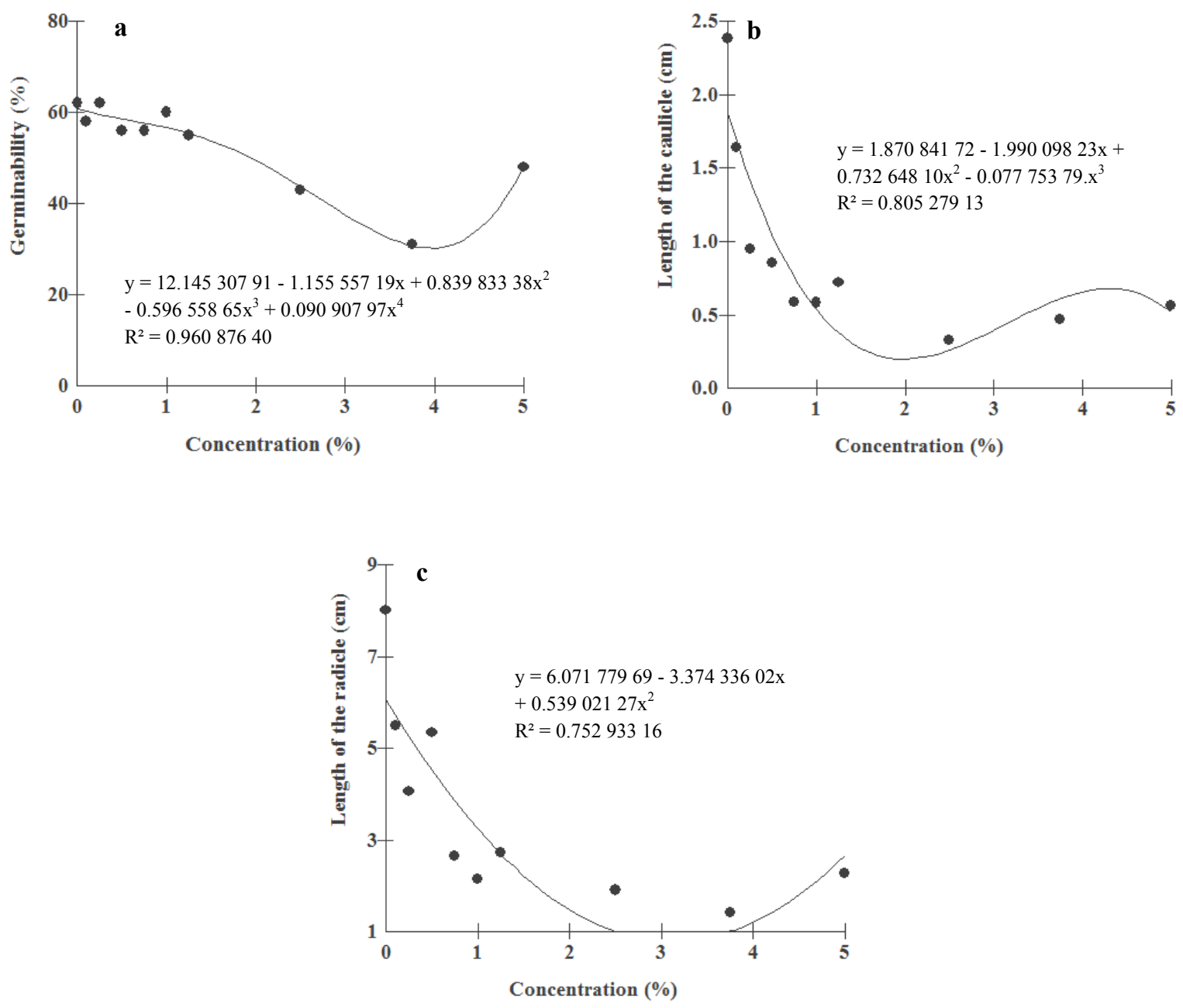

Figure 2. Effect of essential oil of fresh leaves of $C$. limae at concentrations of $0.10 ; 0.25 ; 0.50 ; 0.75 ; 1.00 ; 1.25$; $2.50 ; 3.75$ and $5.00 \%$ on average values of germination index (A), caulicle length (B) and radicular length of seedlings of L. esculentum (C)

Table 3. Analysis of variance of seeds germination and caulicle and radicle length of seedlings of L. esculentum. Subject to effects of essential oil from fresh leaves of $C$. limae

\begin{tabular}{lllll}
\hline \multirow{2}{*}{ Sources of Variation } & \multirow{2}{*}{ DF } & \multicolumn{3}{c}{ MS } \\
\cline { 3 - 5 } & & $\mathrm{G}$ & Length of the caulicle & Length of the radicle \\
\hline Treatments & 9 & $19.26444^{*}$ & $2.00557^{* *}$ & $21.88750 * *$ \\
Residue & 40 & 5.31000 & 0.09008 & 1.55300 \\
$\mathrm{CV}(\%)$ & & 21.70 & 33.08 & 34.57 \\
\hline
\end{tabular}

Note. $* *$ significance at $1 \%, *$ significance at $5 \%$ by Ftest $; \mathrm{CV}=$ coefficient of variation; $\mathrm{MS}=$ mean squares; $\mathrm{DF}=$ degrees of freedom; $\mathrm{G}=$ germination.

\section{Discussion}

\subsection{Chemical Analysis of Essential Oil}

Other species of Croton have presented a chemical composition partly similar to the one found in our research; as in the case of Compagnone et al. (2010), who found $\alpha$-pinene, $\beta$-pinene, $\beta$-myrcene, linalool, $\beta$-caryophyllene, alloaromadendrene, spathulenol and cedrol in the chemical composition of Croton micans Muell. Arg. and Croton matourensis Aubl.. However, there is a divergence regarding the majority compounds present; for the 
leaf oil of $C$. micans, the majority ones were fenchyl acetate (25.3\%). $\beta$-caryophyllene $(20.7 \%)$, $\alpha$-selinene $(12.8 \%)$ and for the flower oil of C. micans, fenchyl acetate (41.6\%), $\beta$-caryophyllene $(12.6 \%)$ were shown to predominate.. For C. matourensis leaf oil, the majority compounds were fenchyl acetate (19.5\%), metyleugenol $(14.2 \%)$ and isoelimicine (11.3\%). Still others present a chemical composition totally divergent from that found in this study, as is the case of Croton zehntneri Pax \& K. Hoffm. (estragol variety), which presented 1,8-cineole, eugenol, mircene, biciclogermacrene, $\beta$-ocimene and sabinene in the composition of its leaf essential oil (Costa el al., 2008).

Various studies have shown that phenylpropanoids, such as anetol and compounds derived from eugenol which are present in fennel, clove and basil oils, are among the main components of the essential oils of the species of Croton found in many places of the world, such as Croton malambo H. Karst. and Croton cuneatus Klotzsch in Venezuela (Suárez, Vásquez, Manzano, \& Compagnone, 2005), Croton pseudoniveus Lundel and Croton suberosus Kunth in Mexico (Perez-Amador, Monroy, \& Bustamante, 2003), C. zehntneri and C. nepetifolius in Brazil (Morais et al., 2006b).

A study carried out on the essential oil extracted from different parts of Croton blanchetianus Baill. (leaves, flowers, roots and trunk bark) collected in different regions of the state of Ceara at different times of the day enabled the investigation and identification of 32 compounds. Among these, the majority compounds were $\beta$-phellandrene (20.4\%) in the leaves, bicyclogermacrene (29.1\%) in the flowers and also in the leaves (17.7\%), $\beta$-elemene (17.8\%) in the flowers and also (22.0\%) in the trunk bark, cyperene $(14.2 \%)$ in the roots and $D$-germacrene (12.8\%) in the trunk bark (Dourado \& Silveira, 2005).

The diversity of chemical composition found in the distinct species of Croton could be due to the richness of this genus in terms of the number of species.

Souza et al. (2006) analyzed the chemical composition of the fixed oil of $C$. cajucara bark from a regional market ("Ver o peso" market, located in Belém, state of Pará, Brazil) and noted the occurrence of cycloisosativene, $\alpha$-copaene, ciperene, $\alpha$-bergamotene, 2,6-dimethyl-6-(4-methyl-3pentenyl), bicyclo [3.1.1] hep-2-eno, cis-cariofileno, alloaromadendrene, $\alpha$ - longipinene, $\delta$-guaiene, $\alpha$-muurolene, $\delta$-cadinene, nerolidol, spathulenol, viridiflorol. Only the compounds alloaromadendreno, linalool and spathulenol found by Souza et al. (2006) matched with the compounds detected in this study.

According to a bibliographical survey carried out by Torres (2008) the compounds most commonly found in Croton species studied in Brazil were diterpenes, which form the class of terpenoids and alcaloids.

\subsection{Effects of Allelopathic Activity of Essential Oil}

According to Sisodia and Siddiqui (2010) the aqueous extracts of roots, trunks and parts of the leaves of Croton bonplandianus Baill at concentrations of 2 and 4\% significantly inhibited the growth of seedlings of Triticum aestivum L., Brassica oleracea var. botrytis L., Brassica rapa L., Melilotus albus Medik., Vicia sativa L., and Medicago hispida Gaertn. The inhibitory effect was greatest on seedlings of M. albus.

The fact that many chemical compounds present in the essential oil of C. limae present allelopathic activity has been substantiated by many authors. $\beta$-pineno inhibited the germination and development of Salvia leucophylla Greene, reducing the mitotic rate of the apical region of the roots (Nishida, Tamotsu, Nagata, Saito, \& Sakai, 2005). According to Zunino and Zygadlo (2004), eucalyptol inhibited the Zea mays L. (corn) root growth through induction of oxidative stress by the production of malondialdeidos, conjugated diene and peroxids. Cedrol inhibited the growth of Echinochloa crus-galli (L.) P. Beauv. roots (He et al., 2006).

Singh, Batish, Kaur, Arora and Kohli (2006), analyzing the allelopathic effect of $\alpha$-pinene in the germination and establishment of seeds of Triticum aestivum L. "HD-2329" (wheat), Cassia occidentalis L. (coffee), Amaranthus viridis L. (green amaranth), Cicer arietinum L. "GL-470" (chickpea) and Pisum sativum L. "AP-1" (pea), noted inhibition of germination of the first three species and inhibition of radicle growth of all of the species tested. The exposure to $\alpha$-pineno caused a rupture of the membrane resulting in an excessive liberation of ions. This occurred due to an oxidative stress caused by increased production of reactive oxygen species (ROS). It also promoted increased levels of malondialdehyde or MDA (the main thiobarbituric acid-reactive species, or TBARS) in C. occidentalis roots. According to Almeida, Zucoloto, Zetun, Coelho, and Sobreir (2008), most of the allelochemicals produce ROS which trigger oxidative stress. The ROS can act directly or indirectly as signaling in cellular degradation processes, disabling germination, initial development and vital physiological process for the plants.

Various types of stress, including environmental and pollutant, biotic and abiotic, promote the production of ROS causing oxidative stress production. Plant cells possess specific enzymes for the production of ROS 
(Desikan, Hancock, Neill, \& Bogatek, 2005). The ROS, $\left({ }^{1} \mathrm{O}_{2}, \mathrm{O}_{2}{ }^{-}, \mathrm{OH}^{-}\right.$e $\left.\mathrm{H}_{2} \mathrm{O}_{2}\right)$, are highly reactive molecules that can affect the permeability of the membrane, causing damage to DNA, proteins, lipids and photosynthetic pigments (Smirnoff, 2005; Weir, Park, \& Vivanco, 2004; Almeida, Zucoloto, Zetun, Coelho, \& Sobreir, 2008). The increase in lipid peroxidation and the leaking of electrolytes resulting in the loss of membrane integrity are among the factors which determine cell damage. The generation of ROS and the related oxidative stress has recently been proposed as one of the forms of activity of plant growth inhibition by allelochemicals (Weir et al., 2004; Blokhina, Virolainen, \& Fagerstedt, 2003).

According to Souza-Filho, Vasconcelos, Zoghbi, and Cunha (2009), the biological activity presented by a certain allelochemical substance is determined by its concentration and by the limit of the response from the affected species. In the case of inhibition, the limit is not constant; it depends on the sensibility of the receptor species, the metabolic and physiological processes of the plant and the environmental conditions.

Considering that the cytotoxic action of $\alpha$-pinene, $\beta$-pinene, eucalyptol and cedrol has been proved, it can be concluded that these compounds are among those responsible for the cytotoxic activity cited of $C$. limae and that they probably act in synergy. These compounds possibly act to promote the increase of ROS production, thus enabling oxidative stress. It can be possible that the consequences of this oxidative stress cause the cellular membrane rupture, but also damage DNA, proteins, photosynthetic pigments or lipids. Essential oil fractionation studies are fundamental to determine which compound or compounds are responsible for the phytotoxicity noted for C. limae.

The essential oil of $C$. limae is composed of 14 compounds, with cedrol, eucalyptol and $\alpha$-pinene being the main ones. The compounds cited, together or isolated, are able to inhibit the germination of tomato seeds at concentrations of $2.50 \%$ and upwards and also inhibit the caulicle and radicle development of tomato seedlings at all the concentrations tested.

\section{Acknowledgements}

To Dr. Margareth Ferreira de Sales from Herbarium Sérgio Tvares (HST) of the Federal Rural University of Pernambuco (UFRPE) for the botanical identification, to the Federal University of Piauí (UFPI) for the chemical analysis of the essential oil and to Fundação Cearense de Apoio ao Desenvolvimento Científico e Tecnológico (FUNCAP), for the research funding.

\section{References}

Adams, R. P. (2001). Indentification of essential oil components by gas mass spectroscopy. Illinois: Allured Publishing Corporation.

Almeida, G. D., Zucoloto, M., Zetun, M. C., Coelho, I., \& Sobreir, F. M. (2008). Estresse oxidativo em células vegetais mediante aleloquímicos. Revista Facultad Nacional de Agronomía - Medellín, 61(1), 4237-4247.

Almeida, S. P., Proença, C. E. B., Sano, S. M., \& Ribeiro, J. F. (1998). Cerrado: Espécies vegetais úteis. Planaltina: EMBRAPA-CPAC.

Blokhina, O., Virolainen, E., \& Fagerstedt, K. V. (2003). Antioxidants, oxidative damage and oxygen deprivation stress: A review. Annals of Botany, 91, 179-194. http://dx.doi.org/10.1093/aob/mcf1 18

Carneiro, V. A., Santos, H. S., Arruda, F. V. S., Bandeira, P. N., Albuquerque, M. R. J. R., Pereira, M. O., ... Teixeira, E. H. (2011). Casbane diterpene as a promising natural antimicrobial agent against biofilm-associated infections. Molecules, 16, 190-201. http://dx.doi.org/10.3390/molecules 16010190

Compagnone, R. S., Chavez, K., Mateu, E., Orsini, G., Arvelo, F., \& Suárez, A. I. (2010). Composition and cytotoxic activity of essential oils from Croton matourensis and Croton micans from Venezuela. Records of Natural Product, 4(2), 101-108.

Costa, J. G. M., Rodrigues, F. F. G., Angélico, E. C., Pereira, C. K. B., Sousa, E. O., Caldas, G. F.R. ... Santos, P. F. (2008) Composição química e avaliação da atividade antibacteriana e toxicidade do óleo essencial de Croton zehntneri (variedade estragol). Revista Brasileira de Farmacognosia, 18(4), 583-586. http://dx.doi.org/10.1590/S0102-695X2008000400015

Desikan, R., Hancock, J., Neill, S., \& Bogatek, R. (2005). Reactive oxygen species as signaling molecules. In N. Smirnoff (Ed.), Antioxidants and reactive oxygen species in plants (pp. 169-196). Oxford: Blackwell Publishing. 
Dourado, R. C. M., \& Silveira, E. R. (2005). Preliminary investigation on the volatile constituents of Croton sonderianus Muell. Arg.: Habitat, plant part and harvest time variation. Journal of Essential Oil Research, 17, 36-40. http://dx.doi.org/10.1080/10412905.2005.9698823

Gniazdowska, A., \& Bogatek, R. (2005). Allelopathic interactions between plants. Multisite action of $\begin{array}{llll}\text { allelochemicals. } \quad \text { Acta } & \text { Physiologiae }\end{array}$ http://dx.doi.org/10.1007/s11738-005-0017-3

He, H., Lin, W., Wang, H., Chen, X., Jia, X., Fang, C., ... Wu, W. (2006). Allelopathic effects of several oxygenic terpenoids on barnyardgrass. Allelopathy Journal, 18(2), 32-32.

Matos, F. J. A. (2000). Plantas medicinais (2nd ed.). Fortaleza: Imprensa Universitária-UFC.

Molina, D. (2010). Estudo traça perfil do mercado de agrotóxicos no Brasil. ANVISA. Retrieved from http://portal.anvisa.gov.br

Morais, S. M., Cavalcanti, E. S. B., Bertini, L. M., Oliveira, C. L. L., Rodrigues, J. R. B., \& Cardoso, J. H. L. (2006b). Larvicidal activity of essential oils from Brazilian Croton species against Aedes aegypti L. Journal of the American Mosquito Control Association, $161-164$. http://dx.doi.org/10.2987/8756-971X(2006)22[161:LAOEOF]2.0.CO;2

Morais, S. M., Júnior, F. E. A. C., Silva, A. R. A., Neto, J. S. M., Rondina, D., \& Cardoso, J. H. L. (2006a) Atividade antioxidante de óleos essenciais de espécies de Croton do nordeste do Brasil. Química Nova, 29(5), 907-910. http://dx.doi.org/10.1590/S0100-40422006000500004

Nishida, N., Tamotsu, S., Nagata, N., Saito, C., \& Sakai, A. (2005). Allelopathic effects of volatile monoterpenoids produced by Salvia leucophylla: inhibition of cell proliferation and DNA synthesis in the root apical meristem of Brassica campestris seedlings. Journal of Chemical Ecology, 31(5), 1187-1203. http://dx.doi.org/10.1007/s10886-005-4256-y

Oliveira Junior, D. A., Silva, R. A., Araújo, L. L., Santos Júnior, R. J., \& Arnaud, A. F. (2008). Caracterização fenológica das plantas apícolas herbáceas e arbustivas da microrregião de Catolé do Rocha - PB - Brasil. Revista Verde, 3(4), 86-99.

Peres, F., \& Moreira, J. C. (2007) Saúde e ambiente e sua relação com o consumo de agrotóxicos em um pólo agrícola do estado do Rio de Janeiro, Brasil. Caderno de Saúde Pública, 23(4), 612-621. http://dx.doi.org/10.1590/S0102-311X2007001600021

Perez-Amador, M. C., Monroy, M. A., \& Bustamante, G. (2003). Essential oil in leaves of Croton pseudoniveus \& C. suberosus (Euphorbiaceae) species. Phyton, 53, 109-112.

Scariot, A., Silva, J. C. S., \& Felfili, J. M. (2005). Ecology and conservation of the cerrado. Brasília: MMA.

Silva, G. B., Martim, L., Silva, C. L., Young, M. C. M., \& Ladeira, A. M. (2006). Potencial alelopático de espécies arbóreas nativas do Cerrado. Hoehnea, 33(3), 331-338.

Singh, H. P., Batish, D. R., Kaur, S., Arora, K., \& Kohli, R. K. (2006). $\alpha$-Pinene inhibits growth and induces oxidative stress in roots. Annals of Botany, 98(6), 1261-1269. http://dx.doi.org/10.1093/aob/mcl213

Sisodia, S., \& Siddiqui, M. B. (2010). Allelopathic effect by aqueous extracts of different parts of Croton bonplandianum Baill. on some crop and weed plants. Journal of Agricultural Extension and Rural Development, 2(1), 022-028.

Smirnoff, N. (2005). Antioxidants and reactive oxygen species in plants (pp 169-196). Oxford: Blackwell Publishing. http://dx.doi.org/10.1002/9780470988565

Souza Filho, A. P. S., Vasconcelos, M. A. M., Zoghbi, M. G. B., \& Cunha, R. L. (2009). Efeitos potencialmente alelopáticos dos óleos essenciais de Piper hispidinervium C. DC. e Pogostemon heyneanus Benth sobre plantas daninhas. Acta Amazonica, 39(2), 389-396. http://dx.doi.org/10.1590/S0044-59672009000200018

Souza, M. A. A., Souza, S. R., Veiga Jr, V. F., Cortez, J. K. P. C., Leal, R. S., Dantas, T. N. C., \& Maciel, M. A. M. (2006). Composição química do óleo fixo de Croton cajucara e determinação das suas propriedades fungicidas. Revista brasileira de farmacognosia, $16 \quad$ (Supl.), 599-610. http://dx.doi.org/10.1590/S0102-695X2006000500004

Suárez, A. I., Vásquez, L. J., Manzano, M. A., \& Compagnone, R. S. (2005). Essential oil composition of Croton cuneatus and Croton malambo growing in Venezuela. Flavour and Fragrance Journal, 20, 611-614. http://dx.doi.org/10.1002/ffj.1498 
Torres, M. C. M. (2008). Estudo químico e biológico de Croton regelianus Var. matosii (Euphorbiaceae) (Master's dissertation, Universidade Federal do Ceará, Fortaleza, Brazil). Retrieved from http://www.repositorio.ufc.br/handle/riufc/9400

Weir, T. L., Park, S. W., Vivanco, J. M. (2004). Biochemical and physiological mechanisms mediated by allelochemicals. Current Opinion in Plant Biology, 7, 472-479. http://dx.doi.org/10.1016/j.pbi.2004.05.007

Zunino, M. P., Zygadlo, J. A. (2004). Effect of monoterpenes on lipid oxidation in maize. Planta, 219, $303-309$. http://dx.doi.org/10.1007/s00425-004-1216-7

\section{Copyrights}

Copyright for this article is retained by the author(s), with first publication rights granted to the journal.

This is an open-access article distributed under the terms and conditions of the Creative Commons Attribution license (http://creativecommons.org/licenses/by/3.0/). 